\title{
Editorial
}

\section{Materials Research - Ibero-american Journal of Materials}

"Judicious and educative"

This $47^{\text {th }}$ issue of Materials Research contains 23 original articles, whereas around 100 are under review.

The table below indicates the level of exposure of the top ten Mat. Res. articles based on the cumulative number of downloads from SciELO - Scientific Electronic Library Online (www.scielo.br/mr):
The top ten articles have been downloaded more than 8,000 times suggesting a significant visibility of Mat. Res and the gradual incorporation of this journal in the national and international techno-scientific literature. We thus expect that its impact factor will steadily increase in the next few years.

Top ten Materials Research articles

- 16,648 downloads: BIANCHI Eduardo Carlos, SILVA Eraldo Jannone da, CEZAR Fabio Andreassa Guedes, et al. Aspectos microscópicos da influência dos processos de esterilização em pontas diamantadas. Mat. Res., 2003; 6(2):203-210.

- 11,145 downloads: BOTELHO Edson Cocchieri, SILVA Rogério Almeida, PARDINI Luiz Cláudio, et al. A review on the development and properties of continuous fiber/epoxy/aluminum hybrid composites for aircraft structures. Mat. Res., 2006; 9(3):247-256.

- 11,061 downloads: SCHNEIDER Sergio, SCHNEIDER Sandra Giacomin, SILVA Helena Marques da, et al. Study of the non-linear stress-strain behavior in Ti-Nb-Zr alloys. Mat. Res., 2005; 8(4):435-438.

- 10,447 downloads: FURTADO Heloisa Cunha, MAY Iain Le. High temperature degradation in power plants and refineries. Mat. Res., 2004/ 7(1):103-110.

- 9,418 downloads: ROGERO Sizue Ota, LUGÃO Ademar Benévolo, IKEDA Tamiko Ichikawa, et al. Teste in vitro de citotoxicidade: estudo comparativo entre duas metodologias. Mat. Res., 2003; 6(3):317-320.

- 8,544 downloads: COTA André Barros, OLIVEIRA Fernando Lucas Gonçalves, BARBOSA Anderson Luiz da Rocha, et al. Microstructure and mechanical properties of a microalloyed steel after thermal treatments. Mat. Res., 2003; 6(2):117-121.

- 8,475 downloads: SEIDEL Juliana Matos, MALMONGE Sônia Maria. Synthesis of polyHEMA hydrogels for using as biomaterials. Bulk and solution radical-initiated polymerization techniques. Mat. Res., 2000; 3(3):79-83.

- 8,397 downloads: REIS Elizabeth Fonseca dos, CAMPOS Fábia S, LAGE Andrey Pereira, et al. Synthesis and characterization of poly (vinyl alcohol) hydrogels and hybrids for rMPB70 protein adsorption. Mat. Res., 2006; 9(2):185-191.

- 8,297 downloads: PAIVA Jane Maria Faulstich de, MAYER Sérgio, REZENDE Mirabel Cerqueira. Comparison of tensile strength of different carbon fabric reinforced epoxy composites. Mat. Res., 2006; 9(1):83-90.

- 8,196 downloads: MELO Rogério AA, GIOTTO Marcus V, ROCHA João, et al. MCM-41 ordered mesoporous molecular sieves synthesis and characterization. Mat. Res., 1999; 2(3):173-179.

Recent statistics indicate that about $60 \%$ of the articles submitted to Mat. Res. are published (after minor or major corrections). The average time from submission to publication is 6 months, whereas the time for rejection varies from 1 to 6 months.

At present Materials Research is indexed by the Science Citation Index-Expanded (SCIE), which includes the Web of Science, ISI Alerting Service and Materials Science Citation Index (MSCI), Chemical Abstracts, World Ceramic Abstracts, International Pool of Glass Abstracts, Scopus and SciELO.

We gratefully acknowledge the Brazilian funding agencies $\mathrm{CNPq}$ and CAPES for their continuous support in covering most of the editorial and printing costs of Mat. Res. The help from the Department of Materials Engineering, Federal University of São Carlos DEMa/UFSCar) for mailing expenses; the Vitreous Materials Laboratory LaMaV/UFSCar) for fax and telephone expenses are also acknowledged. Associação Brasileira de Metalurgia, Materiais e Mineração $(\mathrm{ABM})$ and Associação Brasileira de Polímeros (ABPol) cover the editorial assistant's salary. Associação Brasileira de Cerâmica - ABC, ABPol, and ABM have also helped advertising Materials Research and managing its subscriptions and financial resources. 